\title{
The Role of Intellectual Capital in Facilitating Knowledge Management Practices
}

\author{
Morvarid Khajeh $^{1}$, Taghi Mahallati ${ }^{2}$, Azad Shaibani ${ }^{3} \&$ Sayehmir Khodarahmi ${ }^{4}$ \\ ${ }^{1}$ MBA/Master of Applied Finance, University of Newcastle, Newcastle, Australia \\ ${ }^{2}$ M.A. in Public Management, Faculty of Management, Islamic Azad University, Central Tehran Branch, Tehran, \\ Iran \\ ${ }^{3}$ M.A. in Entrepreneurship, Faculty of Accountancy \& Management Department, Allameh Tabatabaei, Tehran, \\ Iran \\ ${ }^{4}$ M.A. in Public Management, Faculty of Management, Islamic Azad University, Central Tehran Branch, Tehran, \\ Iran
}

Correspondence: Morvarid Khajeh, MBA/Master of Applied Finance, University of Newcastle, Newcastle, Australia. E-mail: drasgari.n@gmail.com

Received: May 2, 2014 Accepted: June 5, 2014 Online Published: August 29, 2014

doi:10.5539/jms.v4n3p184 URL: http://dx.doi.org/10.5539/jms.v4n3p184

\begin{abstract}
Successful implementation of Knowledge management for organization requires a systematic and comprehensive perspective about various organizational factors. Appropriateness of these factors and their integration and coordination is a vital perquisite for implementing knowledge management effectively. The primary purpose of the research is investigating the relationship between three fundamental aspects of intellectual capital-human capital, structuralcapital and relational capital — with knowledge management practices. The research method is descriptive and correlational. The population of the research consists of managers and senior experts of the government state of one of the south states of Iran. A sample of 120 subjects was selected by simple random sampling. According to the research findings there are significant relationship between these intellectual capitaland knowledge management practices. These findings support the necessity of preparing the perquisites of effective implementation of knowledge management. Accordingly an organization characterized by more developed intellectual capitals can benefit from knowledge management initiatives.
\end{abstract}

Keywords: knowledge management, human capital, structural capital, relational capital

\section{Introduction}

At Today's competitive world, organizations should be ready to deal with great changes. The purpose of this preparation is not only technological and equipment readiness and equipment, organizations need to make their employees ready i.e. their main and valuable human (Abdollahi \& Nave Ibrahim, 2006:11). Parallel to the organizational development, relations between employees and agencies have become more complex. With continuous displacement of employees, the most important asset of the organization, its knowledge will be in danger. In the absence of effective management, the main part of knowledge that had been created through these relationships will be ruined. The possibility of the risk for this tacit knowledge is more than explicit knowledge (Fei, 2001:10). The increasing importance of knowledge as determining factorof organization success and competitiveness has resulted in forming Knowledge-based economy and has transformed the management of this important asset to the most fundamental task of organization (Monavarian \& Asgari, 2009). Because of all these, organizations are trying to become a learning organization through creating, maintaining, transferring and application knowledgeto improve their activities and performance (Lee \& Choi, 2003:180). Knowledge management refers to efforts that take place systematically to find, to organize and to make accessible the intellectual capital of the organization and to strengthen the culture of learning and knowledge sharing in organizations (Kapelli, 2000:12). Many of the organizations with focusing on knowledge management and extensive investment in IT are trying to improve their performance by implementing knowledge management (Rastogi, 2000). Faced with this situation, the first wave of efforts is to improve productivity and organizational effectiveness based on hardware installation and use of updated IT equipment and gradually social-human factors 
attracted increasing attention, there were efforts to integrate software and brain ware with above. From Davenport \& Prusak's point of view (2000), most organizations have took primary technological steps and equipment needed to improve level of organizational productivity, but they have reached a constant situation that makes no other added value for them.. Reversing this situation requires major changes and focusing on key aspects such as culture, structure and other socialareas including benefiting organizational capitals (Davenport \&Pozac, 2000: 101).

In such conditions, gaining competitive advantage and sustainable productivity requires to change the behavior of all members in all layers and this also depends on changing beliefs and attitudes of people. Changes in behavior and attitudes also are not possible with simple steps including buying the technology and necessary tools and renaming the traditional phenomena to a new one and pretending to follow the leading organizations and there is a need to have a comprehensive approach along the hardwareaspects, pays attention to social-human factors.

For descriptions of these factors, the term "Intellectual capital" can be used. Concept that meanscombination ofintangible propertymarkets, Intellectual property, Human property and infrastructure property that organization makes to perform its activities (Brookings, 1996). Therefore, the effective management and development of these capitals can help to improve success and competitive advantage of organization.

The fundamental question in this study is whether there is a relationship between the intellectual capital and knowledge management? And the development of these intellectual capitalscan help to improve effectiveness of knowledge management practices?

\section{The Theoretical Literature}

\subsection{Intellectual Capital}

One The most practical definitions of intellectual capital is presented by Organization for Economic Cooperation and Development (OECD): the economic value constitutes intangible capital of organization, first Organizational (Structural) Capital Stewart and then human capital that includes human capital inside (employees of an organization) and outside human resource including customers and suppliers (OECD, 2000). Other scholars like other Bontis (1999), Rossand colleagues (1997), Brooking (1996) and Stewart (1997) reviewed the literature of intellectual capital.

Conceptualintellectual capitalis vague and complex but when used and perceived, it can be a source of competitiveness of the organization (Bontis, 1996: 41). Bontis in another definition introduces intellectual capital as an effort to effective use of knowledge (final product) against information (raw data). Combination of intangible property of markets, intellectual property, human property and infrastructure property enable organization in performing its activities (Brookings, 1996). Ross and his colleaguesalso believe intellectualcapital Intellectual includesall processes and assets that are notoften presented in the Balance sheet and includes all intangible capital (e.g., brands, copyright of products and trademarks) that are paid attention in advanced accounting methods. Intellectual capital includes the total knowledge of organization members and application of their knowledge (Ross et al, 1997: 413). Intellectual capital includes Knowledge, information, intellectual capitalandexperience that can be used for wealth creation. Intellectual capital includes a set of collective mental abilities or key knowledge (Skyrme, 2003).

Table 1. Comparison of various conceptualizations of various intellectual capital (Bontis et al., 2000: 85).

\begin{tabular}{llll}
\hline Brooking ( UK ) & Ross (UK) & Thomas Stewart (United States) & Nike Bontis (Canada) \\
\hline $\begin{array}{l}\text { Human Capital skills, abilities, } \\
\text { expertise, problem solving } \\
\text { abilities and leadership styles }\end{array}$ & $\begin{array}{l}\text { Human Capital, } \\
\text { competence, attitude and } \\
\text { intellectual Agility }\end{array}$ & $\begin{array}{l}\text { Human capital ,employeesas } \\
\text { the most important asset of } \\
\text { organization }\end{array}$ & $\begin{array}{l}\text { Human capital ,Knowledge of } \\
\text { employees }\end{array}$ \\
\hline $\begin{array}{l}\text { Infrastructurecapital, technology, } \\
\text { processes and working methods }\end{array}$ & $\begin{array}{l}\text { Organizational } \\
\text { capital, intellectual asset, } \\
\text { innovation, processesand }\end{array}$ & $\begin{array}{l}\text { Structural capital, available } \\
\text { knowledge about information } \\
\text { technology }\end{array}$ & $\begin{array}{l}\text { Structural capital, non-human } \\
\text { capital or required } \\
\text { organizational capabilities for } \\
\text { meeting market desires }\end{array}$ \\
\hline $\begin{array}{l}\text { Intellectual capital ,technical } \\
\text { knowledge ,trademarks and } \\
\text { copyright }\end{array}$ & $\begin{array}{l}\text { Modernization and } \\
\text { development } \\
\text { capital ,products and } \\
\text { educational efforts' } \\
\text { copyright }\end{array}$ & $\begin{array}{l}\text { Structural capital,product } \\
\text { copyright, designs and } \\
\text { trademarks }\end{array}$ & $\begin{array}{l}\text { Intellectual capital against } \\
\text { intellectual capital, intellectual } \\
\text { asset as a registered asset with } \\
\text { legal definition }\end{array}$ \\
$\begin{array}{l}\text { Relationship capital, } \\
\text { relationships with } \\
\text { customer loyalty, distribution } \\
\text { channels }\end{array}$ & $\begin{array}{l}\text { Customer capital, market } \\
\text { information to use in attracting } \\
\text { and maintaining customers }\end{array}$ & $\begin{array}{l}\text { Relationship capital,customer } \\
\text { capital is only a part of } \\
\text { available knowledge in } \\
\text { organizational relationships. }\end{array}$ \\
\hline
\end{tabular}


Table 1 shows the comparison of intellectual capital from Brooking, Ross, Stwart and Bontis's view. Although definitions of intellectual capital are not completely identical, the overall integration in its concept can be seen. In general, scholars of intellectual capital area have consensus on its three main structure: human capital, structural capital and customer capital.

\subsection{Human Capital}

From Ross and colleagues' point of view (1997) employees create intellectual capital through competencies, attitudes and their intellectual agility. Competency includes skills and education of an individual; The attitude is a behavioral part of what employees do. And intellectual agility also enables an individual to change trends and thinking about innovative solutions. Brooking believes thehuman capital of organizations includes skills, expertise, abilities of problem solving and leadership styles (Brooking, 1996). Chen and colleagues (2004) introduce human capital as a basic of intellectual capital that refers to factors of knowledge, skill, competency and attitudes of employees and leads to improve performance and to increase profitability. This knowledge and expertise lives in the mind of employees, if Intellectual employees are not employed by an organization, the knowledge and expertise in their mind can not be activated and becomes a market value. In table 2, the indicators of human capital are provided.

Table 2. Indicators of human capital (Chen et al., 2004:195)

\begin{tabular}{ll}
\hline $\begin{array}{l}\text { Competency of } \\
\text { employees }\end{array}$ & $\begin{array}{l}\text { Strategic leadership ofmanagement; traits of employees; learning ability of employees, efficiency of employees } \\
\text { training, employees ability for taking part in decision making and management ,training of technical and } \\
\text { managerial employees }\end{array}$ \\
\hline $\begin{array}{l}\text { Attitudes of } \\
\text { employees }\end{array}$ & $\begin{array}{l}\text { Gaining identity from organizational values, the rate of satisfaction, rate of employees' turnover, the average } \\
\text { useful life of employees }\end{array}$ \\
\hline $\begin{array}{l}\text { Creativity of } \\
\text { employees }\end{array}$ & ability of employees' creativity, incomes of employees' creative thinking \\
\hline
\end{tabular}

Based on Chen and colleagues perspective (2004) competency of employees is the rough part of human capital. Competency includes knowledge, skills, talents that among them knowledge and skills are the most important ones. The knowledge related to technical and scientific aspects and it is obtained mostly by education and thus it is theoretical. The skills and capabilities of doing tasks are mostly obtained by experience, however they can be developed by education. Attitude of employees is a soft part of human capital and includes motivation and job satisfaction. The attitude is considered as precondition of incidence of competencies of employees. Some companies such as Mc Kense, Procter and Campbell believe in similar importance for both attitudes of employees and their competencies.

Bontis (1998) describes human capital as collective capabilities of organization for extraction of best solutions from knowledge of its employees. According to his belief (1998) human capital causes the dependency of organization mostly on knowledge and skills of its employees to create income and development and to improve efficiency and productivity.

\subsection{Capital Structural}

Youndth (2000) knows organizational capital as an internalized knowledge of organization that is saved in databases, guidelines and etc. Structural capital includes all non-human capitals of knowledge in organization that includes databases, organizational charts, executive guidelines of processes, strategies, executive programs and anything that have a higher intellectual value than its material value (Ross et al., 1997). According to Ross and colleagues' perspective (1997) structural capital is anything that when employees leave office after work, it will remain there. Based on their belief structural capital includes organizational capital such as intellectual capital, innovation, processes and cultural capital and also modernization and development capital such as product copyright. From the perspective of Stewart (1997), structural capital also includes knowledge of information technology, product copyright, designs and trademarks.According to the belief of Chen and colleagues (2004) structural capital refers tosystem,structure and Current procedures of businesses in an organization.in table 3 the indicators of structural capital have been provided. 
Table 3. Indicators of structural capital (Chen et al., 2004)

\begin{tabular}{ll}
\hline $\begin{array}{l}\text { Organizational } \\
\text { culture }\end{array}$ & Creating organizational culture, gaining employee identity from perspective of organization \\
\hline $\begin{array}{l}\text { Organizational } \\
\text { structure }\end{array}$ & The clear relationship between authority, responsibility and benefits, the credit of control system in organization \\
\hline $\begin{array}{l}\text { Organizational } \\
\text { learning }\end{array}$ & $\begin{array}{l}\text { Creation and application of information network inside organization, creation and application of organizational } \\
\text { information resources }\end{array}$ \\
\hline Operational process & Period of business process; quality level of product; operational and organizational efficiency \\
\hline Information system & $\begin{array}{l}\text { Mutual support And cooperation Between Employees; ability to access to organizational information; } \\
\text { knowledge sharing }\end{array}$ \\
\hline
\end{tabular}

If organization has weak systems, intellectual capital cannot reach to the most of its potential ability. Organizations which have strong structural capital also have supportive culture that enables individuals to do new things, to cope with failure and to learn. Accordingly, it can help structural capital of employees in optimal intellectual performance and improving business performance of organization. Structural capital is a function of human capital because human capital also is one of the determining factors of organizational foundation. On the other hand, structural capital influences human capital. So while interacting, these two can help organization to form coordinately customer capital and to develop and to use it (Chen et al., 2004:195).

\subsection{Customer/Relational Relationship}

Customer capital means using market information in order to attract customers and to maintain them. The main topic of customer capital is the available knowledge in marketing channels and relations with customers. Customer capital indicates the potential ability of organization because of external intangible factors (skyrme, 2003). Although the word "customer capital" firstly introduced by Hubert Saint-Onge, its new definition of its concept has been developed as relational capital and constitutes available knowledge in all relationships that organization establishes with customers, rivals, suppliers , business associations or government (Bontis, 1999:433). Ross and colleagues (1997) also think relational capital includes relationships with internal and external stakeholders of organization. A sign of relational capital related to customers is marketorientation. Kohli \& Jaworski (1990) think this market orientation includes creating sagacity in market at organizational level according to available and future needs of customers. At last, the development of this sagacity is done horizontally and vertically in organization in a way that it can improve accountability of organization to market changes (Bontis, 1999:399).

Chen and colleagues (2004) categorize customer capital in a form of marketing capability, market intensity and customer loyalty (table 4). Based on marketing capability, company can manage its capital. By increasing market intensity and customer loyalty, company first has to increase main marketing capability such as service offer capability and collecting capability and application of customer data.Market intensity indicates the final limit of close competition of today. A company that has no loyal customers should adjust different sales policies in a way to attract new customers who sometimes are not profitable. Accordingly, company should try a lot in order to improve product quality and services related to current and future needs of customers and to increase customer satisfaction and as a result to increase customer loyalty. Generally, customer capital acts as a bridge or intermediate in intellectual capital process and is the main determining factor in transforming intellectual capital to market value and consequently business performance of organization. Without customer capital, market value or business performance of organization cannot be accomplished. So the growth of customer capital depends on supporting human capital and structural capital (Chen et al., 2004:195).

Table 4. Indicators of customer capital (Chen et al., 2004:195)

\begin{tabular}{ll}
\hline $\begin{array}{l}\text { fundamental } \\
\text { marketing } \\
\text { capability }\end{array}$ & creation And application of customer database; customer service capability; ability to identify customer needs \\
\hline $\begin{array}{l}\text { Market } \\
\text { intensity }\end{array}$ & Market share; potential ability of market; sale department; the fame of trademarks and brand, creating sale channel \\
\hline $\begin{array}{l}\text { Customer } \\
\text { loyalty }\end{array}$ & Customer satisfaction; customer complaints ,customer defection; investments on relations with customers \\
\hline
\end{tabular}

\subsection{Knowledge Management}

Karl Wiig propagated the concept of knowledge management first in 1986. Wiig knows knowledge management 
as making and renewal process, application and exploiting knowledge in order to maximize effectiveness of organization knowledge and returning its knowledge capital. Since then there were many efforts to define management.Nevertheless, the definition of knowledge management is complex and the reason is many interpretations of different perspectives and its related areas (Martin, 2000:170). Knowledge management means development and exploitation of knowledge capital of organization .In other words, knowledge management refers to systematic and integrated procedure of coordinating vast activities of organization including gaining, creating, storing, sharing and applying knowledge by individuals and groups in order to reach organizational objectives (Rastogi, 2002). Although about procedure of knowledge management there have been different perspectives provided, main stages of this procedure includes following foursteps (Monavarian \& Asgari, 2009).

Knowledge Creation: Knowledge is obtained in fact through experience and skills of employees. Knowledge is created when individuals find new method to do things or develop substantive knowledge. Knowledge creation results from social interaction and organizational cooperation (Alavi \& leidner, 2001). Knowledge storage: It may be that peopleforget the knowledge they have created, so it is necessary to store, to organize and to retrieve this knowledge in organizational memory. Organizational memory includes different forms of written documents, databases and coded human knowledge in a form of expert systems, documentation of procedures and organizational trends (Anvari \& Shahabi, 2009).

Knowledge application: The ultimate goal of knowledge management is knowledge application in order to improve organizational performance. Knowledge itself is not valuable, but it will be valuable the time it is used (Anvari \& Shahabi, 2009).

Knowledge sharing: knowledge sharing is a process of spreading knowledge across the organization. This can be done between individuals, groups and organizations that use any kind of communication channels (Alavi \& leidner, 2001). Knowledge sharing includes five main pillars: a value of knowledge source, source tendency to knowledge sharing, media richness of communication channel, receiver tendency to receive knowledge and compensation ability of receiver (Gupta \& Govindarajan, 2000).

\section{Theoretical Framework}

Based on the literature described, four dimensional procedure of knowledge management (Nonaka \& Takio chi, 1994) are considered as dependent variable and intellectual capitals (human, structural and customer capitals) also as independent variables. Figure 1 shows the conceptual model of the study.
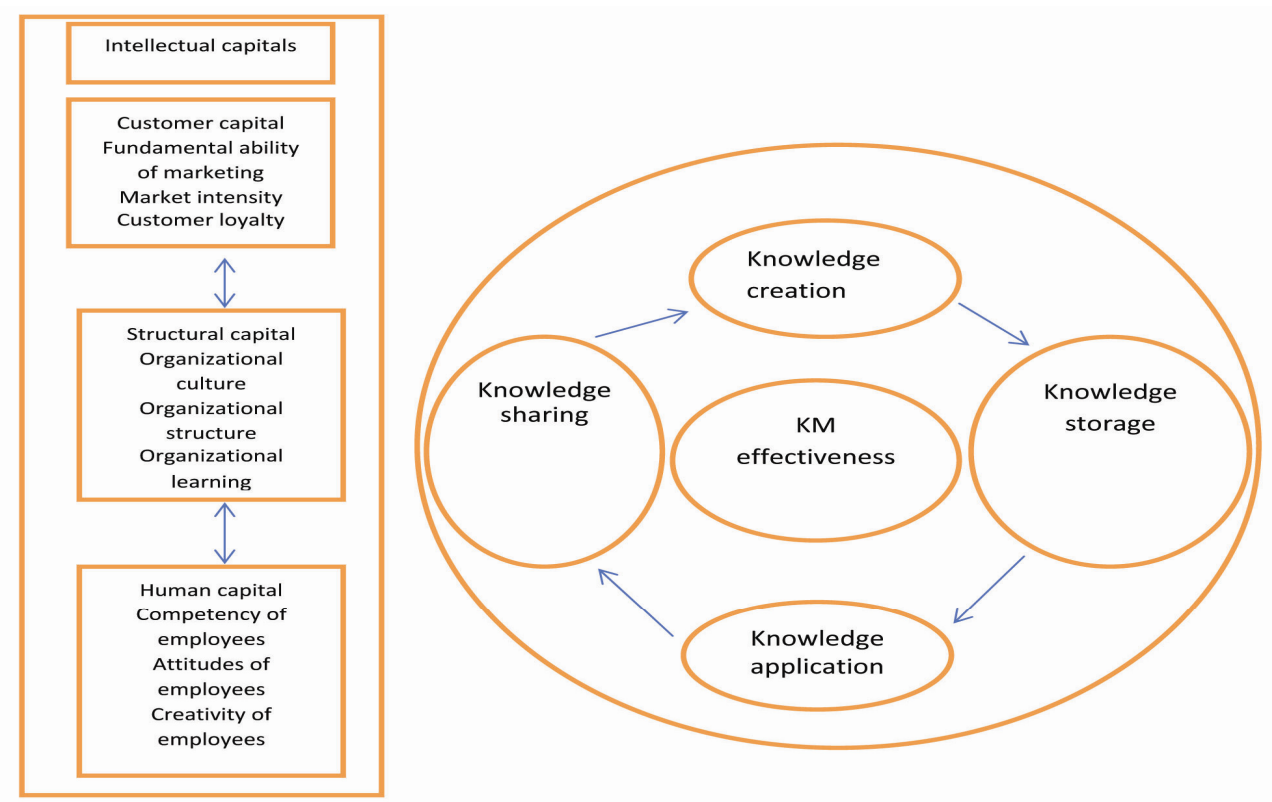

Figure 1. Conceptual model of study

\section{Research Hypotheses}

Based on the literature reviewed in this study, the following hypotheses will be examined: 
The main theory: Intellectual capitals have a positive and significant impact on improving effectiveness of knowledge management measures.

\subsection{Sub-Hypotheses}

1) Human capital has a positive and significant effect on improving the effectiveness of knowledge management measures.

2) Structural capital has a positive and significant effect on improving the effectiveness of knowledge management measures.

3) Relational capital has a positive and significant effect on improving knowledge management measures.

\subsection{Type of Research and Study Tool}

The purpose of this study is descriptive and the type of use is applicable and based on time aspect is cross-sectional and based on data type is quantitative. Instrument used to collect data is questionnaire. Validity results of each component separately using Cronbach's alpha test is as follows: creation and acquisition component: 0.70; Knowledge storage: 0.78 ; knowledge sharing: 0.78 ; knowledge application: 0.79 ; human capital: 0.70 ; structural capital: 0.75 ; relational capital (customer orientation): 0.74 , and the entire questionnaire were 0.72 . Because the Cronbach's alpha is greater than 0.7 (baseline), validity of the questionnaireis confirmed.Confirmatory factor analysis was used to assess the validity of the questionnaire on which validity was confirmed.

\subsection{Statistical Sample and Population}

The study sample includes 200 experts and managers of government in one the southern province in Iran. 120 people were selected by using stratified random sampling.

\subsection{Methods of Data Analysis}

In this study, the analysis of structural equation modeling has been used to analyze data obtained from the samples and to investigate the presence or absence of concurrent relationships between variables.

In the structural equation modeling of relations between traits extracted based on the theory, were investigated according to collected data. After modeling, special indicators were used to assess the validity of model that includes the ratio of Chi square to freedom degree that must be less than 3 which is allowable, the allowable value of root mean square ofapproximation error must be less than 0.08 and Pi must be less than 0.05 and the adjusted goodness of fit index must be greater than 0.9 (Kalantari, 2009). In order to examine the significance of effect of intellectual capitals on effectiveness of human knowledge management measures, the model of significance and to assess the quality and the amount of this effect the standard model has been used. About the significance of the obtained numbers, it can be said because the hypotheses test is done in 0.95 of confidence level, numbers will be significant that are not between 1.96 and -1.96 . This means that if a number is not between 1.96 and $-1.96 \mathrm{~T}$ it will not be significant.

In order to investigate the relationship between the hypotheses, first the significance of effect of each predicted relationshipis examined by using significance modeling and then the amount and quality of each relationships effect is assessed by using standard modeling. Thus the results of assessing research hypothesescan be summarized in table 5 based on the results obtained.

Table 5. The results of examining hypotheses

\begin{tabular}{|c|c|c|c|c|}
\hline Hypothesis & Route & $\begin{array}{l}\text { Standardized } \\
\text { coefficients }\end{array}$ & $\begin{array}{l}\text { Significant } \\
\text { numbers }\end{array}$ & Result \\
\hline Main & $\begin{array}{l}\text { Positive and significant effect of intellectual capitals on effectiveness of } \\
\text { knowledge management measures }\end{array}$ & 0.87 & 13 & Confirmed \\
\hline 1 & $\begin{array}{l}\text { Positive and significant effect of human capital on effectiveness of } \\
\text { knowledge management measures }\end{array}$ & 0.87 & 12.30 & Confirmed \\
\hline 2 & $\begin{array}{l}\text { Positive and significant effect of structural capital on effectiveness of } \\
\text { knowledge management measures }\end{array}$ & 0.88 & 9.33 & Confirmed \\
\hline 3 & $\begin{array}{l}\text { Positive and significant effect of customer capital on effectiveness of } \\
\text { knowledge management measures }\end{array}$ & 0.54 & 7.87 & Confirmed \\
\hline
\end{tabular}

The general pattern of relationships between variables in structural equation modeling was consistent with the assumptions statedall four investigated hypotheseswere significant and important. Based on the results obtained, conducting effective knowledge management measures has an important and significant effect on human 
capitals.Accordingly based on thesemeasures, knowledge management had the greatest determining effect on creativity of employees.

\section{Conclusion and Suggestions}

The overall pattern of relationships between independent and dependent variables in structural equation modeling were consistent with the stated hypotheses, all 4 hypotheses were important and significant. Based on the results obtained, the positive effect of human, structural and customer capitals on effectiveness of knowledge management measures has been approved thus it can be said that the strengthening and developing these intangible capitals can provide suitable infrastructure to improve effectiveness of knowledge management system in organization. In order to improve intellectual capitals, we will provide recommendations on three following pillars:

A) In order to strengthening each of human capital components, the following recommendations are provided;

- Designing a competency framework of employees and managers including knowledge and skills , their ability and planning by them based on competency

- A continuous measurement of competency level of employees and use of programs of succession planning in different organizational levels.

- Ongoing assessment of employees performance in the certain period and analysis of obtained results from measuring employees performance and comparing them with standards and measures such as incentives and punishment.

- Designing system of support and encouragement of superior minds of employees in order to implement them timely in the organization's operational processes and giving appropriate feedback and using 360 degrees feedback.

- Establishing measurement system of job satisfaction in an organization and continuous measurement of job satisfaction of employees.

B) To strengthen each part of structural capital (organizational structure, organizational culture, operational process, and...) suggestions below were provided:

- Using advanced structures like team and project structures in the different areas of organization.

- Identifying those key processes that have the highest value for the customers, and documenting these processesand identifying and implementing domestic and international rivals' experience.

- Assigning more funding and time for research and operational development and cooperation and interaction with authorities and scientific associations and the use of information systems that makes it easy to access information.

- Using the suggestions regime inside organization in order to get comments of employees and outside of organization to get comments of customers.

C) To strengthen the relationship between each of the relational capital components (fundamental capability of marketing, market intensity and customer loyalty) suggestions below are provided:

- Training appropriate behavior to employees and individuals who have direct relationship with customers.

- Identification of customers.

- Continuous tracking and responding to complaints and expectations of customers in a timely manner and the automation of certain customer affairs.

- Implementing strategic planning to identify opportunities and threats in the external environment and internal strengths and weaknesses during adjusting contracts and agreements.

\section{References}

Abdollahi, B., \& Nave Ibrahim, R. A. (2006). Empowering employees, golden key of human resource management. Tehran: Virayesh publication.

Afrazeh, A. (2004). Knowledge Management: Concepts, Models and, Measurements and Implementation. Tehran: Amir Kabir university press.

Alavi, M., \& Leidner, D. E. (2001). Review: Knowledge Management and Knowledge Management Systems: Conceptual Foundations and Research Issues. MIS Quarterly, 25(1), 107-136. http://dx.doi.org/10.2307/3250961 
Anvari, A. A., \& Shahabi, B. (2009). Knowledge management and the learning organization: an analysis of the role of documentation of knowledge and experience. Journal of Technology Information management, 1(2), 3-18.

Bintis, N. (1998). Intellectual capital: an exploratory study that develops measures and models. Managing Decision, 36, 63-76. http://dx.doi.org/10.1108/00251749810204142

Bintis, N. (1999). Managing organizational knowledge by diagnosing intellectual capital: framing and advancing the state of the field. International Journal of technology Management, 18(5/6), 433-62. http://dx.doi.org/10.1504/IJTM.1999.002780

Bontis, N. (1996). There is a price on your head: managing intellectual capital strategically. Business Quarterly, Summer, 41-47

Brooking, A. (1996). Intellectual capital. London: International Thompson Business Press.

Capelli, P. (2000). A market driven approach to retaining talent. Harvad Business Review, 76(2).

Chen, J., Zhu, Z., \& Xie, H. Y. (2004). Measuring intellectual capital: a new model and empirical study. Journal of Intellectual Capital, 5(1), 195-212. http://dx.doi.org/10.1108/14691930410513003

Davenport, T. H., \& Prusak, L. (2000). Working knowledge: How organizations manage what they know? Boston, MA: Harvard business school press.

Fei, G., Meng, L., \& Yoshiteru, N. (2001). Systems thinking on knowledge and its management: systems methodology for knowledge management. Journal of Knowledge Management, 6(1).

Gupta, A. K., \& Govindarajan, V. (2000). Knowledge Management's Social Dimension: Lessons from Nucor Steel. Sloan Management Review, 42(1), 71-80.

Kalantari, K. (2009). Structural equation modeling in social-economic research.

Kelly, J. (1998). Those who can and those who can not: winner and loser in the digital age. Vital Speeches of the Day 65. No 3.

Lank, E. (1997). Leveraging invisible capital: the human factor. Long Range Planning, 30(3), 406-412. http://dx.doi.org/10.1016/S0024-6301(97)90258-2

Lee, H., \& Choi, B. (2003). Knowledge Management enablers, process and organizational performance: An Integrative view and empirical Examination. Journal of Management Information Systems, 20(1).

Martin, B. (2000). Knowledge management within the context of management: An evolving relationship. Singapore Management Review, 22(2), 17.

Monavarian, A., \& Asgari, N. (2009). Organization in the industrial age, information and knowledge. Tehran: Tehran University Press.

Nonaka, I. (1994). A dynamic theory of organizational knowledge creation. Organizational Science, 5(1), 14-37. http://dx.doi.org/10.1287/orsc.5.1.14

Organisation for Economic Co-operation and Development (OECD). (2000). Final report: Measuring and Reporting Intellectual Capital: Experience, Issues, and Prospects. Paris: OECD.

Rastogi, P. N. (2000). Knowledge management \& intellectual capital—The new virtuous reality of competitiveness. Human Systems Management, 9(1), 39-49.

Roos, G., \& Roos, J. (1997). Measuring your Company's Intellectual Performance. Long Range Planning, 30(3), 413-426. http://dx.doi.org/10.1016/S0024-6301(97)90260-0

Rowley, J. (2000). Knowledge organization for a new millennium: principles and processes. Journal of knowledge Management, 4(3), 217-223. http://dx.doi.org/10.1108/13673270010350011

Skyrme, D. (2003). Knowledge management making sense of an oxymoron.

Zahedi, S. A. (2003). The role of new communication technologies in democratic management of society.

\section{Copyrights}

Copyright for this article is retained by the author(s), with first publication rights granted to the journal.

This is an open-access article distributed under the terms and conditions of the Creative Commons Attribution license (http://creativecommons.org/licenses/by/3.0/). 